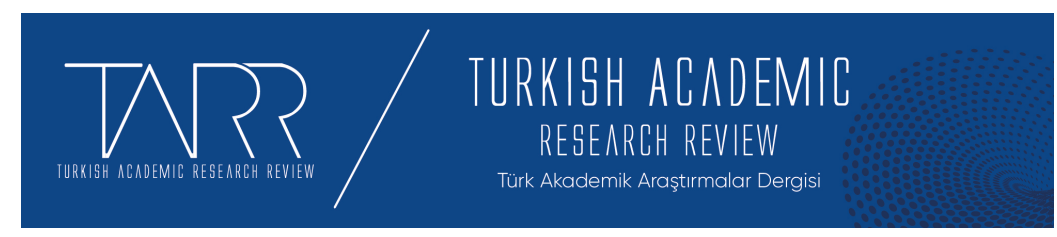

e-ISSN: 2602-2923 Yll/Year: 2021 Cilt/Volume: 6 Sayı/Issue: 3

\title{
Bir Bildungsroman Örneği Olarak El-Bâhis ‘Ani’l-Hakîka
}

\author{
el-Bâhith 'An al-Haqiqa As A Bildungsroman
}

\section{Encümen BAYRAM}

Dr. Öğr. Gör., A.Ü. İlahiyat Fakültesi / Akdeniz University, Faculty of Divinity, encumenbayram@akdeniz.edu.tr, Orcid ID: 0000-0001-6891-3680

\begin{tabular}{r|l} 
Makale Bilgisi & Article Information \\
Makale Türü - Article Type & Araştırma Makalesi / Research Article \\
Geliş Tarihi - Date Received & 31 Ağustos / August 2021 \\
Kabul Tarihi - Date Accepted & 16 Eylül / September 2021 \\
Yayın Tarihi - Date Published & 20 Eylül / September 2021 \\
Yayın Sezonu & Temmuz - Ağustos - Eylül \\
Pub Date Season & July - August - September
\end{tabular}

Atıf / Cite as: Akça, İ. (2021), Bir Bildungsroman Örneği Olarak el-Bâhis 'Ani'lHakîka/el-Bâhith 'An al-Haqiqa As A Bildungsroman. Turkish Academic Research $\begin{array}{lllll}\text { Review, } & 6 & \text { (3), } & 955-968 . & \text { Retrieved }\end{array}$ https://dergipark.org.tr/tr/pub/tarr/issue/64962/989139

Intihal / Plagiarism: Bu makale, en az iki hakem tarafından incelenmiş ve intihal içermediği teyit edilmiştir. / This article has been reviewed by at least two referees and confirmed to include no plagiarism. https://dergipark.org.tr/tr/pub/tarr

Copyright (C) Published by Mehmet ŞAHIN Since 2016- Akdeniz University, Faculty of Theology, Antalya, 07058 Turkey. All rights reserved.

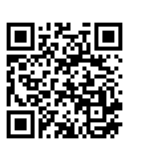

Turkish Academic Research Review - Türk Akademik Araştırmalar Dergisi 




\title{
Bir Bildungsroman Örneği Olarak el-Bâhis ‘Ani’l-Hakîka
}

\author{
Encümen BAYRAM
}

\section{$\ddot{O} z$}

Roman, anlatmaya dayalı bir türdür. O; kişi, zaman, mekân, olay örgüsü ve anlatım teknikleriyle kendine has bir kimlik edinir. Onun günümüzdeki hüviyetini edinmesi destan, hikâye, menkıbe ve mesnevi gibi klasik anlatımlardan aldığ 1 mirasın sonucudur. Tarihî seyir içerisinde farklı çeşitlerine rastlanan romanın bir türü olan bildungsroman, kendine has kurgusuyla dikkat çeker. Kabul gören ilk bildungsroman, 18. yüzyılda Alman yazar Johann Wolfgang von Goethe tarafindan kaleme alınan Wilhelm Meister's Lehrjahre adlı eserdir. Goethe; burada toy bir erkek kahramanın ahlakî, psikolojik ve entelektüel gelişimini işler. Bu romanda kahramanın kemâle ermesi, fizikî açıdan ziyade içsel olarak kademe kademe değerlendirilir. Bu makalede modern Arap romanının tesisi ve ilk modern romanın mahiyetine dair bilgiler değerlendirilmektedir. Daha sonra Türkçede "oluşum romanı”, Arapçada "رواية التشكيل" ve İngilizcede “coming of age” gibi farkl1 adlarla kendine yer edinen ancak daha çok bildungsroman şeklinde bilinen bu roman türüne ait bilgiler sunulmaktadır. Çalışmada, modern Arap edebiyatının ilk edebî romanı kabul edilen Zeyneb'in bu türdeki aidiyetine bakılarak Arap bildungsromanın tarihî gelişimi üzerinde durulmaktadır. $\mathrm{Bu}$ hususta Arap ve Türk romanında bildungsroman olarak değerlendirilen Hüsn-ü Aşk ve es-Sâk 'alâ's-sâk gibi çalışmalara da değinilerek İbn Tufeyl'in Hay b. Yakzân isimli hikâyesi üzerinden yeniden bir çerçeve çizilmeye çalışılmaktadır. Araştırmanın ana omurgasını olușturan el-Bâhis 'ani'l-hakîka romanının yazarı Muhammed 'Abdulhalîm Abdullah'a, onun modern Arap romanının teşekkülündeki yerinin tespiti için kısaca değinilmektedir. Abdullah'ın yazarlığının son döneminde kaleme aldığı el-Bâhis 'ani'l-hakîka, Selmân b. Fârisî'nin hayatını bildungsroman türünde işlemesi açısından önemlidir. Zira araştırmamız, söz konusu eserin bir bildungsroman olduğu üzerine kurgulanmaktadır. Çalışmamızın Arap bildungsromanı üzerine yapılacak araştırmalara katkı sunması öngörülmektedir.

Anahtar Kelimeler: Bildungsroman, Arap romanı, Muhammed 'Abdulhalîm 'Abdullah, el-Bâhis 'ani'l-hakîka.

\section{el-Bâhith 'An al-Haqiqa As A Bildungsroman}

\begin{abstract}
Novel is a narrative literary genre. It acquires a unique identity with its person, time, place, plot and narrative techniques. Its acquisition of identity today is the result of its legacy from classical narratives such as epic, story, legend and masnavi. Bildungsroman, which is a genre of novel that can be found in different varieties in the historical course, draws attention with its unique fiction. The first accepted
\end{abstract}

Turkish Academic Research Review - Türk Akademik Araştırmalar Dergisi 
bildungsroman is Wilhelm Meister's Lehrjahre, written by the German writer Johann Wolfgang von Goethe in the 18th century. In this work, Goethe deals with the moral, psychological and intellectual development of a naive male character. In this novel, the protagonist's reaching maturity is evaluated gradually, internally rather than physically. In this article, the establishment of the modern Arabic novel and the information about the nature of the first modern novel are evaluated. In addition, the identity acquisition of the modern Arabic novel is presented through the work named Zeyneb by Hüseyin Heykel. Afterwards, information about this type of novel, which is known as bildungsroman, is presented with different names such as "oluşum romani" in Turkish, "رواية التثكيل" in Arabic and "coming of age" in English and it is pointed out that the bildungsroman is mostly fictionalized over its protagonist. In this study, the historical development of the Arabic bildungsroman is emphasized by looking at Zeyneb's belonging to this genre, which is accepted as the first literary novel of modern Arabic literature. As it can be understood from the name of the novel named Zeyneb, although some information is presented about the development of the protagonist with the same name in the fiction, it is evaluated whether it is substantially a bildungsroman or not. At the same time, Zeyneb's literary position is determined and information about other Arabic novels with the same characteristics is shed light on. In this regard, it is tried to redraw a frame through Hay b. Yakzân, which is a story written by İbn Tufeyl, by referring to works such as Hüsn-ü Aşk and es-Sâk 'ala's-sâk, which are considered as bildungsroman in Arabic and Turkish novels. Although it is accepted that this mystical story about the development of Hay, who was raised by a gazelle on a desert island, contributed to the development of both European and Arabic bildungsroman, it is concluded that the work does not belong to the modern novel in terms of its structural features and narrative techniques. Muhammad 'Abdulhalîm Abdullah, the author of the novel alBâhis 'ani'l-hakîka, which constitutes the pillar of the research, is briefly mentioned in order to determine his place in the formation of the modern Arabic novel. The first edition of al-Bahis 'ani'l-hakîka was made in Cairo in 1966 with 143 pages. This novel is a realist and historical work written by Muhammed 'Abdulhalîm 'Abdullah by transforming his literary personality. It is worth noting that the first period of Abdullah's literary personality was romantic, the second period was romantic-realist, and the last period was realist. The novel consists of seven independent parts. AlBâhis 'ani'l-hakîka, which Abdullah wrote in the last period of his authorship, is important in terms of addressing the life of Selmân b. Fârisî in the form of bildungsroman. The main reason why al-Bahis 'ani'l-hakîka is considered as a bildungsroman is the adventure of self-realization the study will contribute to any researches on the Arabic bildungsroman.

Keywords: Bildungsroman, Arabic Novel, Muhammad Abdal-halim Abdallah, elBâhis 'ani'l-hakîka 


\section{Structured Abstract}

Novel is a narrative literary genre. It acquires a unique identity with its person, time, place, plot and narrative techniques. Its acquisition of identity today is the result of its legacy from classical narratives such as epic, story, legend and masnavi. Bildungsroman, which is a genre of novel that can be found in different varieties in the historical course, draws attention with its unique fiction. The first accepted bildungsroman is Wilhelm Meister's Lehrjahre, written by the German writer Johann Wolfgang von Goethe in the 18th century. In this work, Goethe deals with the moral, psychological and intellectual development of a naive male character. In this novel, the protagonist's reaching maturity is evaluated gradually, internally rather than physically. In this article, the establishment of the modern Arabic novel and the information about the nature of the first modern novel are evaluated. In addition, the identity acquisition of the modern Arabic novel is presented through the works named es-Sâk 'ala's-sâk by Faris al-Şidâk and Vay... İzen lestu bifrencî by Halîl elHûrî, İlham fî cinâni'ş-Şam by Selîm el-Bustâmî, Gâdetu'z-zahire by Zeynep Fuyâz and Zeyneb by Hüseyin Heykel. Afterwards, information about this type of novel, which is known as bildungsroman, is presented with different names such as "oluşum roman1" in Turkish, "رواية التشكيل" in Arabic and "coming of age" in English and it is pointed out that the bildungsroman is mostly fictionalized over its protagonist. In this study, the historical development of the Arabic bildungsroman is emphasized by looking at Zeyneb's belonging to this genre, which is accepted as the first literary novel of modern Arabic literature. As it can be understood from the name of the novel named Zeyneb, although some information is presented about the development of the protagonist with the same name in the fiction, it is evaluated whether it is substantially a bildungsroman or not. At the same time, Zeyneb's literary position is determined and information about other Arabic novels with the same characteristics is shed light on. In this regard, it is tried to redraw a frame through Hay b. Yakzân, which is a story written by İbn Tufeyl, by referring to works such as Hüsn-ü Aşk and es-Sâk 'ala's-sâk, which are considered as bildungsroman in Arabic and Turkish novels. Although it is accepted that this mystical story about the development of Hay, who was raised by a gazelle on a desert island, contributed to the development of both European and Arabic bildungsroman, it is concluded that the work does not belong to the modern novel in terms of its structural features and narrative techniques. Muhammad 'Abdulhalîm Abdullah, the author of the novel alBâhis 'ani'l-hakîka, which constitutes the pillar of the research, is briefly mentioned in order to determine his place in the formation of the modern Arabic novel. The first edition of al-Bahis 'ani'l-hakîka was made in Cairo in 1966 with 143 pages. This novel is a realist and historical work written by Muhammed 'Abdulhalîm 'Abdullah by transforming his literary personality. It is worth noting that the first period of Abdullah's literary personality was romantic, the second period was romantic-realist, and the last period was realist. The novel consists of seven independent parts. This novel, which is evaluated as a small-volume novel, has been translated into many languages of the world, especially English, French and Persian, by being converted into children's story and story formats. Due to this feature, it is the most read and known novel among the novels of Abdullah. Abdullah, who lived between 19131970 , is one of the most widely read writers in the Arab society. The fiction of his works decorated with romantic themes is inspired by the countryside. He is called a

Turkish Academic Research Review - Türk Akademik Araştırmalar Dergisi 
"Delta novelist", referring to the Nile delta, because of the fact that he is one of the writers who draw the most attention to the villager and his social structure among the Egyptian writers. Because of these characteristics he has, he is referred to as a village novelist, while his coetaneous Necîb Mahfûz is also referred to as a city novelist. It is also noteworthy that Mahfûz deals with the people of the streets of Cairo. Muhammed 'Abdulhalîm 'Abdullah is also called a "Roman poet" because of the fluent language and style he prefers in his works. It is also noteworthy that he was nicknamed the "Father of Awards" due to the various awards he received for his contributions to the Arabic novel. After an early death, he left thirteen novels, ten story collections and countless interviews to his readers. Al-Bâhis 'ani'l-hakîka, which Abdullah wrote in the last period of his authorship, is important in terms of addressing the life of Selmân b. Fârisî in the form of bildungsroman. The main reason why al-Bahis 'ani'l-hakika is considered as a bildungsroman is the adventure of self-realization that starts in Cey, the village where the protagonist of the novel, Selmân-i Fârisî, was born and ends in Medina. In the novel, a journey is set out through the inner world of the protagonist. Due to the fiction of the novel, Selmân develops morally at the same rate as he grows physically. As a matter of fact, the action of the novel begins when Selmân, who had the best life of the period and was a member of the best social level, opposes the mistakes he sees and feels about beliefs and life. This is not easy for a young character. With fear, panic and excitement, Selmân continues his journey of finally searching and finding himself in different geographies. The protagonist also gets the chance to realize himself with religious values in all the places in question. Based on these issues, our research is based on the fact that the work is a bildungsroman. In this study ultimately it is mentioned about the journey of Selmân b. Fârisî for the sake of self-realization through his beliefs. The struggle for formation that started in the land of Persia, Anatolia, Iraq, Syria and finally ended in Medina draws attention. At the end of all the joy and sorrow that the Persian experienced, his self-realization occurs. The novel takes place as an example of bildungsroman in Arabic literature as it narrates this unique formation of its protagonist, Selmân b. Fârisî. It is foreseen that the study will contribute to any researches on the Arabic bildungsroman.

\section{Giriş}

Türkçeye “oluşum romanı”, (Özdemir, 2018: 500), Arapçaya “رواية التشكيل", İngilizceye "coming of age" (Golban, 2017: 113) şeklinde giren bildungsroman, bir kahramanın akıl ve duygu gibi daha çok manevi yetilerle tarif edilebilecek özelliklerinin kemâle ererek ulaşılan kişilik yapısını ifade eder (Nedal, 2006: 224). $\mathrm{Bu}$ sürecin oluşumunda maddi unsurlar da etkilidir. Ancak kişiyi birey yapan iç dünyası, bu romanda daha çok ön plana çıkar. İlk örneği Alman edebiyatında Goethe'nin kaleme aldığı Wilhelm Meister's Lehrjahre ${ }^{1}$ (Wilhelm Meister'in

${ }^{1} \mathrm{Bu}$ romanda zengin bir tüccarın oğlu olan Wilhelm tiyatroya olan sevdasından dolayı evi terk eder, zamanının büyük bir kısmını tiyatro sevdasıyla ve bu sanatla ilgilenenler içerisinde geçirir. Ancak edindiği tecrübe sonucu hayatta aradığı şeyin burada olmadığını fark eder 
Çıraklık Yılları) (1795) adlı eserle müşahede edilen bu türde, kahraman, yaşadığı çevreye bağlantılı bir süreç içerisinde bir değişim ve olgunlaşma sürecine girer (Asutay, 2012: 28).

Goethe'den önce bu bildungsroman, tanrı-insan ilişkisi içerisinde yorumlanırken; ondan sonra ise onun, birey-birey, birey-toplum ilişkisi çerçevesinde ele alındığı dikkat çeker. Bu romanda, kahramanın kendini keşfetme yolculuğunda içe dönüşler ve içsel sorgulamalar yapması kaçınılmazdır. Hatta kahramanın temel gayelerinin başında kendini gerçekleştirmek vardır. Onun nezdinde toplumdan soyutlanma, değerleriyle çatışma beklenmez; aksine toplumda yer sahibi iyi eğitmenlerin tezgâhından geçmek asıl olandır. Fakat bu, sürekli aranan bir tahkiye durumu değildir. Ancak romanın iç kaideleri çerçevesindeki düğüm bölümünde, kahramanın olgunlaşması yani oluşması gerekir. Zira roman anlatıcının -ki bu çoğu zaman yazarın kendisidir- temel amacı da budur. Aynı zamanda tercih edilen üslup ve anlatı materyali de bu minvalde kullanılır. Ayşe Nur Özdemir'e göre; Romanın bu türü için kurgunun "yetkinleşmesi" üzerine bina edilen bir kahramanın aydınlanması sözkonusudur. Burada kronolojik bir yaşam neticesinde olgunlaşan aydınlanma bir nihayeti de karşılar (Özdemir, 2018: 500). Tüm bu özelliklerden dolayı bildungsroman, bir kahramanın yazarca çok kolay oluşturulmasına olanak da sağlar; aynı zamanda o, kahramana da kendisi olma izni veren roman türlerinin başında gelir (Asutay, 2012: 31).

$\mathrm{Bu}$ türdeki romanın özelliklerini ifade ederken elde edilen bulgulardan anlaşılacağ1 üzere, bütün kurgu başkahramanın kendisini bulması üzerine kurulmaktadır. Bu noktada söz konusu karakterin de başkarakter olması gerekir. Ancak bildungsromana kısa tarihî seyir itibariyle bakıldığında gerek Türk edebiyatında gerekse de Arap edebiyatında türün netliği konusunda birtakım tanım problemlerine rastlanabilmektedir. Söz gelimi Şeyh Gâlip'in en önemli eserlerinden birisi olan Hüsn-ü Aşk, bir anlatı türü olarak mesnevi olmasına rağmen bildungsroman roman türünde değerlendirilmektedir (Bayram, 2007: 12). Benzer şekilde makâme türünde kaleme alınmış Fâris eş-Şidyâk'a ait es-Sâk 'alâ 's-sâk adlı romanın de bu denli değerlendirilmesi dikkat çeker ('Âşûr 2009: 67). Ancak bu eser, Hüsn-ü Aşk'tan farklı olarak Arap edebiyatında ilk romanın hangisi olduğu konusundaki tartı̧̧malardan kaynaklanmaktadır. Nitekim bu konuda ilk Arap romanının Fâris eş-Şidyâk'ın 1855 yılında yayımladı̆̆ı es-Sâk 'alâ's-sâk mı?, Halîl el-Hûrî’nin 1859 yılında yayımladığı Vay...ंzen lestu bifrencî mi?, Selîm el-

sonra ait olduğu topluma ve sosyal sınıfa dönüş yapar. Bu serüven içerisinde Wilhelm kendini gerçekleştirir.

Turkish Academic Research Review - Türk Akademik Araştırmalar Dergisi https://dergipark.org.tr/tr/pub/tarr 
Bustâmî’nin 1870 yılında yayımladığı İlham fỉ cinâni 'ş-Şam mı?, Zeynep Fuyâz'ın 1899 yılında kaleme aldığı Ğâdetu'z-zâhire mi? Hüseyin Heykel'in 1914 yılında yayımladığı Zeyneb adlı eser mi?, olduğu tartışmaları devam ederken ('Âşûr 2009:10) en nihayetinde ilk modern Arap romanının Hüseyin Heykel'in Zeyneb'i olduğu hususunda görüş birliğine varıldığı görülmektedir. (Ürün 2018; 83) Dolayısıyla bildungsromanın bir roman türü olduğundan hareketle bir değerlendirmeye varılması daha doğru olacaktır. Ancak burada Hüsn-ü Aşk ve esSâk 'alâ's-sâk üzerinden yapılan analizlerin Goethe'den önce yapılan çalışmaların ışığı̀nda daha çok karaktere manevî bir yapıyı kazandırma üzerine geliştirilen metinlere atfen gerçekleştirildiği de fark edilmektedir. Nitekim başkaraktere manevî bir kimlik üzerinden gelişim atfedilmesi Arap anlatı tarihi açısından daha öncelere dayanır ve bu belirsizliğin getirdiği tartışmalar Arap bildungsromanın tesisi konusunda farklı bilgi ve algılara yol açar. Kaldı ki modern Arap romanının teşekkülünden çok önce inşa edilen makâme, hikâye ve mesnevi gibi birtakım anlatı türleri için bu minvalde çeşitli tanımların yapıldığı da görülmektedir; özellikle İbn Tufeyl'in Hay b. Yakzân adlı "adasal" türde yazılmış (Kutluer-Katipoğlu 1997: 551) hikâyesini bildungsroman türünde ele alanlarla karşılaşılmaktadır (Özalp 2014: 55). Issız bir adada bir ceylan tarafından büyütülen Hay'ın gelişimini anlatan bu mistik hikâye gerek Avrupa gerekse de Arap bildungsromanının gelişimine katkı sağladığı kabul görse de eserin yapı özellikleri ve anlatım teknikleri açısından modern romana ait olmadığı unutulmamalıdır (Al-Mutairi, 2016: 360).

Nitekim günümüzde yapılacak bildungsroman çalışmalarının bu kıstasların göz önünde bulundurulması ile daha nesnel özelliklere sahip olacağı varsayılmaktadır. Arap anlatı tarihine bakıldığında yapı özellikleri bakımından modern romana en yakın türün makâme olduğu görülmektedir. Ancak bu anlatı türünün teknik açıdan romandan ayrıldığı da bilinmelidir. Konumuzun bu anlatı türlerini belirleme olmadığından hareketle söz konusu tahkiye türlerinin bildungsroman kapsamına alınıp alınamayacağı hususundaki tartışmaların başka bir çalışmanın içerisinde değerlendirilmesi uygun görülmektedir. Ne var ki Arap bildungsroman tarihine bakıldığında başlangıcın Zeyneb romanından sonra yapılması daha doğru olacaktır. Nitekim bir otobiyografik roman örneği olan bu eser, her ne kadar bu çalışmanın dâhilinde ele alınan türe dair birtakım özellikler taşıyor olsa da onu, tamamen bildungsroman çerçevesinde değerlendirmek mümkün değildir. Zira Zeyneb romanında kurgunun Zeyneb adlı başkarakterin aşk hayatı üzerinden yapıldığı görülmektedir: "Zeyneb ilk önce çiftliklerinde çalıştığı köy ağasının oğlu Hamit ile aşk yaşar. Hamit ise bu ilişsiyi sevdiği ve başka biriyle evlenen kuzeni Azize'yi unutmak için başlatır ve Zeyneb'in kendisine uygun 
olmadığını düşünerek onu terk eder. İlk hayal kırıklığından sonra Zeyneb, çalıştı̆̆ çiftlikteki işçilerin kâhyalığını yapan İbrahim adındaki kişiye âşık olur. Bu aşkı karşılık bulur. Ancak İbrahim ödeyecek yeterli başlık parasını bulamadığı için Zeyneb ile evlenemez. Aynı zamanda paralı askerlikten de yararlanamaz ve Sudan'a bu görev için gitmek zorunda kalır. Romanın ilerleyen bölümlerinde Hasan adlı başka bir delikanlı Zeyneb'e talip olur ve evlenirler. Hasan evine bağlı Zeyneb'e karşı çok hoşgörülü ve nazik davranışlar sergiler ancak Zeyneb Hasan'a karşı beslemediği sevgiden dolayı onun bu nazik davranışları karşısında bocalar, kendisiyle hesaplaşması zamanla içinden çıkılmaz bir hal alır. İbrahim'i asla unutamaz ve nihayetinde girdiği bunalımdan kurtulamaz; kederinden vereme yakalanır ve ölür" (Er 2015: 78-79). Romanın kısa özetinden de anlaşılacağı üzere Zeyneb adlı karakter her ne kadar yaşadığı durumdan kurtulmak için kalbinin sesini dinleyerek kendini gerçekleştirmeye çalışsa da bu imkânı asla bulamaz ve hayatını kaybeder. Oysaki bir bildungsromanda insan yaşamında doğal bir süreç olan ölüm anına kadar romanın kahramanııın kendini gerçekleştirmiş olması esastır (Asutay, 2012: 30).

Zeyneb romanını takip eden süreçte Arap edebiyatı açısından önemli ve Arap romanı için ise güzel bildungsroman örneği kabul edilecek eserler dikkat çeker. Bunların başında Mısırlı yazar Tevfîk el-Hakîm'in Fransa'ya okumak için giden Muhsin'in burada bir Fransız kıza âşık olması sonrasında Doğu-Batı arasında kıyaslamalar yaparak bir kimlik edinmesi sürecini anlatan romanı 'Usfûr mine'ş-şark (Doğunun serçesi) (1938) gelmektedir. Aynı zamanda Iraklı yazar Zu'n-Nûn Eyyûb 'Abdulvâhıd'in ed-Duktur İbrâhîm (Doktor İbrahim) (1939), Lübnanlı yazar Suheyl İdris'in el-Heyy'ul-Lâtîn̂ (Latin Mahallesi) (1958), Sudanlı yazar Tayyib Salih'in Mevsimu'l-hicra ilâ'ş-şimâl (Güneye Göç Mevsimi) (1966), Suudi yazar Ğâlib Hamza Ebû'l-Ferec'in Senevâtu'd-diyâ‘(Kayıp yıllar) (1980) adlı eserler gelmektedir. Ürdün akademisyen Musâ Nedal'in "The changing image of the heroine in the Arabic female Bildungsromane", çalışmasında bu türden değerlendirdiği Mısırlı yazar Yahya Hakkı'nın Kandîl Um Hâşîm (Um Haşim'in Lambası) (1944); roman değil, bir hikâyedir. Dolayısıyla da bir bildungsroman olarak değerlendirilmesi mümkün değildir (Nedal 2006: 257).

Diğer yandan yazarının kendi oluşumunu kaleme aldığı birtakım bildungsroman örneği de dikkat çekmektedir: Taha Huseyn'in el-Eyyam romanının çocuk kahramanı Taha Huseyn'in kendisidir, Ibrahim el-Kâtip romanının kahramanı İbrahim, İbrahim 'Abdulkâdir el-Mâzinî iken, Avdetu'r Ruh'taki Muhsin, Tevfik elHakim ve Sâre romanındaki Hemmâm ise Abbas Mahmud el-'Akkad'tır (Badawi 1992: 182). $\mathrm{Bu}$ romanların bildungsroman olarak nitelendirilmesini sağlayan 
başkahramanlarının hepsi erkektir. Başka bir deyişle bu romanlar erkek bildungsroman örnekleridir. Aynı zamanda söz konusu Arap yazarların oluşum romanlarında yer alan konu ve temaların Batı'ya bir yolculuğu içermesi de ilginçtir. Nitekim Batı ile geliştirilen tahkiye düzeyindeki alışveriş; kültürel, politik ve tarihsel faktörlerin gölgesinde orjinal bir Arap bildungsromanın oluşmasına zemin hazırlamıştır (Nedal 2006:258).

$\mathrm{Bu}$ çalışmada yer verilen ancak sahip olduğu özelliklerden dolayı bildungsroman olarak değerlendirilmeyen Zeyneb romanının akabinde başka kadın bildungsromanların da Arap edebiyatında yer aldığı görülür: Bunların başında Lübnanlı yazar Emily Nasrullâh'ın Tuyûru'l-eylûl (Eylül Kuşları) (1962), Mısırlı yazar Miral et-Tahavî'nin el-Bâzincânetu'z-zerkâ (Mavi Patlıcan) (2002), Latîfa ezZeyyâd'ın el-Bâbu'l-meftûh (Açık Kapı) (1960) vb. gelmektedir. Bu türden romanların daha pek çoğuna yakın zamanda yazılanlar içerisinde rastlamak mümkündür (Badawi 1992: 181).

\section{el-Bâhis 'ani'l-hakîka Müellifinin Arap Romanındaki Yeri}

Anlatmaya dayalı bir tür olan romanın çıkış yeri Batı'dır (el-Hâdîb, 1976: 19). Arap dünyasında modern anlamda ortaya çıktığı ilk yer ise Mısır'dır. Son derece etkili bir anlatım geçmişine sahip Arap edebiyatı bu türü özümseme noktasında zorluk yaşamaz. Zira Cahiliye Dönemi'nden başlamak üzere gerek sözlü gerekse de yazılı olarak eşsiz anlatımların varlık gösterdiği bir gerçektir. Mısırlı yazarlar son derece etkili olan edebî geçmişlerine ait anlatı türleri ile romanı harmanlayarak özgün bir Arap romanı inşa etmişlerdir. İlk önceleri Batı’yı taklit ve onun eserlerini uyarlama şeklinde varlık gösteren modern Arap romanı, doğası gereği zamanla mecrasını bulur. Hiçbir yazarın yaşadığı toplumdan uzak duramayacağı gerçeğiyle bağdaşan bu durum, ilerleyen süreçlerde Arap toplumunun sosyal, siyasal ekonomik ve tarihî meselelerini kapsayacak şekilde bir hüviyet kazanır. Bunun anlamı şiir, darb-1 mesel daha sonra eşsiz bir belâgat örneği olan Kur'an-1 Kerîm'deki kıssalarla Arap romanının olgunluk merhalesine girmesidir. Nitekim çeviri ve uyarlamalarla bir temeli başlatan sözü edilen I. kuşaktan sonra gelen ve içerisinde Muhammed ‘Abdulhalîm Abdullah’ın da olduğu II. kuşakla Arap romanı gerçek formuna kavuşur. (Nevfel, 1981: 4).

Eserin Müellifi Muhammed 'Abdulhalîm Abdullah, 1913-1970 y1lları arasında yaşamış Arap toplumunda eserleri en çok okunan yazarlardan birisidir. Romantik temalarla süslü eserlerinin kurgusu kırsala aittir. Mısırlı yazarlar içerisinde köylüye ve onun sosyal yapısına en dikkat çeken yazarların başında gelmesinden dolayı kendisine Nil deltasina atfen "Delta romancisı" denilmektedir. 
Onun sahip olduğu bu özelliklerinden dolayı ona köy romancısı sıfatı atfedilirken, çağdaşı Necîb Mahfûz da şehir romancısı olarak anılmaktadır. Zira Mahfûz'un özellikle Kahire sokaklarının insanını işlediği de bilinmektedir. (Nevfel, 1981: 3).

Pek çok türde eserler veren 'Abdullah'ın en büyük özelliklerinden biri de döneminde revaçta olan halk diyalektinin yazım hayatında sık kullanılmasına karşın Fasih dili tercih etmesidir. Yazar, romanlarında yer verdiği bir köylü karakteri dahi okuyucu nezdinde herhangi bir iğretinin oluşmasına mahal vermeden fasih dille konuşturur. Öyle ki romanlarında tercih ettiği söz konusu dil ve eşsiz üslubundan dolayı da kendisine "Roman şairi" sıfatı layık görülmektedir. "Abdullah Arap romanına katkılarından dolayı aldığı çeşitli ödüller sebebiyle de "Ödüllerin babası" şeklinde bir başka sıfatı da hak etmektedir (Nevfel, 1981: 28).

'Abdullah, daha önce de ifade ettiğimiz üzere II. kuşak Arap romancilar arasında yer alır. Bu kuşak, öz benliğiyle yoğrulmuş, kendine has bir kimlik kazanmış Arap romanını tesis etmiştir. Başka bir ifadeyle öze dönüş projesiyle tarihî, dinî konular ile Filistin gibi güncel meseleleri romanlarında aksiyona dâhil etmiştir. Nitekim yazarlığının ilk dönemlerinde daha çok romantik konuları işleyen Muhammed 'Abdulhalîm 'Abdullah 1967 yılındaki Arap-İsrail savaşındaki hezimetten sonra ve dinî inancının etkisiyle Selmân b. Fârisî’nin hayatını kurguladığı el-Bâhis 'ani'l-hakikka adlı romanını kaleme almıştır (el-Ka'ûd, 1976: 132).

'Abdullah sahip olduğu dil-üslup, romanlarında işlediği tema ve konularla kendinden sonraki Arap yazarlara örnek bir miras bırakmıştır.

\section{Bir Bildungsroman Olarak el-Bâhis 'Ani'l-Hakîka}

Eserin ilk baskısı, 1966 yılında Kahire'de 143 sayfa olarak yapılmışıtır. Bu roman, Muhammed 'Abdulhalîm 'Abdullah'ın edebî kişiliğinde bir dönüşüme giderek yazmış olduğu realist ve tarihî bir eser olma hüviyetine sahiptir. Roman, bağımsız yedi bölümden oluşmaktadır. Küçük hacimli romanlar içerisinde değerlendirilen bu eser, çocuk hikâyesi, hikâye formatlarına da dönüştürülerek dünyanın başta İngilizce, Fransızca, Farsça olmak üzere pek çok diline çevrilmiştir. $\mathrm{Bu}$ özelliğinden dolayı yazara ait romanlar içerisinde en çok okunan ve bilinen roman olma vasfı da taşımaktadır.

'Abdullah, İngiliz romancı Thomas Hardy'nin Jude Fawley adındaki başkarakterin gelişimini kurguladığı ve bu sahada önemli bir eser kabul edilen Jude the Obscure (Bilinmeyen Jude ) (1971) adlı romanından etkilenmiştir (Nâcî, 2009: 26). Söz konusu etkilenme başkarakterin hedeflerine ulaşma ve bu uğurda sarf ettiği çabalar düzeyindedir. Zira tema bağlamında her ne kadar dine vurgu yapılsa da bu

Turkish Academic Research Review - Türk Akademik Araştırmalar Dergisi https://dergipark.org.tr/tr/pub/tarr 
durum el-Bâhis 'ani'l-hakîka'da olduğundan farklıdır. el-Bâhis 'ani'l-hakîka, başkahraman Selmân-1 Fârisî’nin gelişimini kapsamaktadır. Onun çocukluktan geç dönem gençliğine kadar devam eden yaşantısı ele alınmaktadır.

Anlatmaya dayalı bir tür olan romanın doğası gereği anlatımın gerçek hayattan biraz kopuk olması muhtemeldir. Nitekim romanın başkahramanı olan Selmân-1 Farisî’nin kişilik bilgilerinin Arif Aytekin'in “Delâilü'n-nübüvve' ye Konu Teşkil Eden İki Sahâbî: (Selmân-1 Farisî ve Abdullah b. Selâm)” adlı derinden işlenen çalışmasında onun hayatından farkl1lıklar ihtiva ettiği görülmektedir (Aytekin 2017: 30). Buna rağmen romandaki konu ve temalar, tarihî realiteden uzak değildir.

el-Bâhis 'ani'l-hakikk'nın bir bildungsroman olarak değerlendirilmesinin en başında, romanın başkahramanı Selmân-1 Farisî’nin doğduğu köyü Cey'den başlayan ve Medine'de noktalanan kendini gerçekleştirme serüvenidir. Romanda daha çok başkahramanın içsel dünyası üzerinden bir yolculuğa çıkılmaktadır. Selmân, fizikî olarak büyüdükçe aynı oranda da ahlakî bakımdan gelişmektedir. Romanın başkahramanının konuşmak ve öznel kişiliğini göstermek (Golban, 2017: 112) gibi vasıfların bildungsroman türünün önceliği olduğu realitesinden hareketle Selmân-1 Fârisî’nin oluşumunun da bu iki çizgi üzerine inşa edildiği dikkat çeker. Roman; çocuk yaşta dönemin en iyi yaşantısına sahip, en iyi toplumsal kademesine mensup olan Selmân'ın inanç ve yaşantı konusunda gördüğü ve hissettiği yanlışlara karşı çıkmasıyla başlar.

Romanın kurgusunun merkezi daha evvel belirttiğimiz gibi İsfahan'ın bir kırsalıdır. Selmân'ın babası Dahkan, burada büyük bir Mecusî imamıdır. O, ailesine çok düşkündür ve Selmân'ı "benliğim" şeklinde çağırır ve sever. Ailenin iyi bir yaşantısı vardır. Babanın aile içerisindeki olumlu davranışları, aile bireylerine gösterdiği sevecenlik ve merhamet hizmetinde bulunanlar için tam tersidir. Nitekim Selmân'ın benliğini bulma noktasında ilk tepkisi, babasının çobanlarını falakaya yatırarak dövdüğü bir aksiyonla başlar ('Abdullah ts: 14,15). O, kendine sonsuz merhameti olan; fakat diğerlerine karşı ise aynı derecede nefreti olan bir adamın dininin gerçek ilahî bir din olamayacağı fikrine kapılır. Böylece benliği oluşturan gerçek dinin peşine dolayısıyla kendini bulmanın macerasına atılır ve evi terk eder.

Romanın kurgusunda, Selmân'ın köyünden ve ailesinden ayrılışı kendine dönüşü ifade eder. Bu durum, küçük denecek yaştaki bir kahraman için kolay değildir. Selmân, korku, panik ve heyecanla kendini arama ve bulma yolculuğuna çıkar. İlk durağı Şam'dır. Ancak Selmân, buraya ulaşıncaya kadar kafasında çok sayıda soru vardır ve bu soruların cevaplarını aramaktadır. Nihayetinde en temel sorunun bireyin benliğini oluşturan inancının sağlam olmamasında olduğu fikrine 
ulaşır. Şam'daki durağından sonra ziyarette bulunduğu ve zaman geçirdiği Musul, Nusaybin ve Ammûriyye gibi mekânlarda tanıştığı farklı kültürdeki şahıslar da onun kişiliğinin oluşmasında etkendir. Böylece Hristiyan inancının öğretisini edinmeye ve bu din üzere yaşamını sürdürmeye karar verir. Bu merhale aynı zamanda onun kişiliğini din eksenli yönlendireceği anlamına da gelir. Zira Selmân, kişiliğinin oluşumuna yön verecek bir hakikatin peşindedir.

Romanın ilerleyen bölümlerinde Selmân, babasının dini olan Mecusilikten daha iyi olduğuna inandığı Hristiyanlığa mensup kişilerin davranışlarından dolayı bu dinin de insanı kâmil kılan bir din olmadığı kararına varır ("Abdullah ts: 68). Bu karara Hristiyanların kişilik analizlerini yaparak ulaşır. Zira hile, yalan ve kavga gibi durumların insan fitratına aykırı olduğuna inanır. İște bu inancı, onu Yahudiliğe yönlendirir. Aslında Selmân'ın buraya kadar olan süreçte yaptığı dinler arası yolculukların temelinde kendini bulma vardır. Yahudilik dinine intisabı sırasında Nusaybin'dedir ancak burada yanında kaldığı din adamı hasta yatağındayken onu başka bir Yahudi din adamının yanına gönderir. Selmân'ın “Âbit” diye hitap ettiği yeni yoldaşının babacan davranışlarından dolayı son derece memnundur. $\mathrm{O}$, Selmân'a elinin emeğiyle bir yaşam kazanmayı öğretir ('Abdullah ts: 60-67). Zira beraber ekip biçtikleri ve ürünlerini sattıkları bir arazileri vardır. Oldukça saygın olan ve sık sık ziyaret edilen Âbit yaşlıdır. O, hayat tecrübesinden Selmân'nın ne aradığını anlar ve bir gün Selmân'a şöyle der: “Gözlerin ölümümden sonra nereye gideceğini sorar gibi, ancak içinde bulunduğumuz durumu kimse bilmez. Beni iyi dinle! Hz. İbrahim'in Hanif diniyle yollanacak bir peygamberin zamanı yaklaştı. Yapabilirsen iki taşlık arazi arasındaki palmiyeli yere git." ("Abdullah ts:74). Selmân, Âbit’ten ayrılacağından bu duyduklarına karşı çıkar. Ancak sözüne çok itimat ettiği Âbit'in dediklerini yerine getirmek ve Hak Peygamber'iyle bir araya gelmek için yeniden yollara düşer ('Abdullah ts: 83). Koyunlarıyla beraber bir kafileye katılır. Ancak kafilenin reisi Selmân'ın koyunları yük olur ve onların hızını düşürür bahanesiyle satar. Daha sonrada Selmân’ı Ebu Ya‘kûb adında bir yahudi tüccara ücret karşıllı̆ında köle olarak verir (“Abdullah ts: 89).

Tüm bu olanları içsel bir kabulle karşılayan Selmân, Allah’a iyi bir kul olmanın ve hak dini üzere bir kişilik tesis etmenin peşindedir. Onun farklı dinleri kabulünün ve efendiye itaat etmesinin gerisinde aciz bir kişilik yoktur aksine yaşantıdan ders çıkararak bir benlik oluşturma gayesi vardır. Nitekim efendisi Ebu Ya‘kûb ona kölelik yapmasını istediği bir aksiyonda Selmân sadece Allah’a köle olabileceğini belirterek, kişiliğinin inşası hususunda ipuçlar verir ('Abdullah ts: 94). Romanın ilerleyen aksiyonlarında Ebu Ya‘kûb Selmân’ı Beni Kurayza kabilesinden Ebu Ka‘b adında başka bir yahudiye köle olarak satar. Ancak bu sırada Selmân,

Turkish Academic Research Review - Türk Akademik Araştırmalar Dergisi https://dergipark.org.tr/tr/pub/tarr 
istediği menzili katederek Âbit'in işaret ettiği iki taşlık arazi arasındaki palmiyeli yere varır. Burası söz konusu kabilenin yaşadığı Yesrîb'tir. ${ }^{2}$ Selmân yeni efendisiyle bu kente girdiğinde şöyle der: "Burası peygamberin topraklarıdır ve ben onunla burada karşılaşacağım” ("Abdullah ts: 99). Bu durum onun hisleri konusunda ne denli emin olduğuna işaret eder ki bireyin duygularına hâkim olması onun oluşumu konusunda son derece kıymetlidir. Bu merhalede Beni Kurayza'ya müntesip kişilere dokuma sanatını göstermesi, çoğu kişinin yapamayacağı işleri güç sarf ederek yapması onun aynı zamanda fiziki oluşumuna da delalettir. $O$, otuz üç yaşında hayatının güçlü dönemlerinden birisindedir ('Abdullah ts: 103). Bildungsromanda kahramanın fikri oluşumunda fiziki yön de son derece önemlidir.

Nitekim Selmân'ın bu aşamada Hassân b. Sâbit ile tanışması, ondan şiirler dinlemesi de onun duygu dünyasını güçlendirmesi noktasında değerlidir ('Abdullah ts: 107). Böylece onun çıktığı yolculuğun duygusal açıdan dayanakları da sağlanmış olur. Ancak bu dönem aynı zamanda başkahraman için sorgulama merhalesidir. Zira o, Hz. Muhammed'in Mekke'den Yesrîb'e geldiği haberini alır. Selmân, O’na gitme ve aynı ortamda bulunma sıkıntısı yaşar. Onun köle olması bu kavuşmadaki en büyük engeldir. Ancak Selmân bir gece kölelik zincirini kırar ve Hz. Muhammed'i görmek için sahibinin evinden ayrılır ve ilk defa O'nun bulunduğu meclise girer ('Abdullah ts: 117). Bu kölelik sistemine aykırı davranış, bir başkaldırıyı temsil ederken aynı zamanda Selmân'ın kişilik oluşumunda kendi istek ve reddini ortaya koyması noktasında önem arz eder.

Selmân, Hz. Peygamber’le tanışır ve müslüman olur ('Abdullah ts: 121). İlerleyen aksiyonda Selmân, Hz. Peygamber'in girişimiyle fidyesi ödenerek kölelikten kurtulur ('Abdullah ts: 123). Böylece gelişim aşamasının en önemli bölümü tamamlanmış olur. Onun kendini gerçekleştirme konusunda sürekli ayağına pranga olan bu durumun değişmesiyle yepyeni bir merhale başlar. Bu, Selmân'ın artık hür bir birey olarak İslâm ordusuna katıldığı, onu yönlendirdiği ve zaferlere koştuğu bir aşamadır. Hatta bu, aynı zamanda Selmân'ın olgunlaştı̆ı merhaledir.

\section{Sonuç}

Bildungsroman, bir roman türü olarak Goethe tarafindan kaleme alınan Wilhelm Meister's Lehrjahre adlı romanla Batı'da neşet etmiştir. Kadim bir sözlü ve yazılı anlatım geleneği üzerinde yükselen Arap romanının modern bir kimlik kazanması da Batı eksenli girişimlerledir. Zira buraya ilk önce tercüme ve

\footnotetext{
${ }^{2}$ Medine Şehri
} 
uyarlamalarla gelen roman, Hüseyin Heykel'in Zeyneb adlı romanıla Batılı bir hüviyet kazanmıştır.

Bazı çevreler, Arap edebiyatındaki ilk bildungsromanın İbn Tufeyl'in kaleme aldığı Hay b. Yakzân adlı eser olduğu kanısını taşır. Ancak bu tasavvur, söz konusu eserin özelliklerinden dolayı onun bir roman vasfı taşımadığını ve dolayısıyla bir bildungsroman olamayacağını doğrular. Ancak onun Batı ve Arap bildungsromanının köklerine nüfuz ettiği de inkâr edilemez.

Hüseyin Heykel'in Zeyneb adlı romanıyla başlangıcı kabul edilen modern Arap romanında çok sayıda bildungsroman örneği karşımıza çıkmaktadır. Bunların içerisinde Muhammed 'Abdulhalîm 'Abdullah'ın kaleme aldığı el-Bâhis 'ani'lhakîka adlı roman müstesna bir yere sahiptir: Şöyle ki eserin Arap romanının öz kimliğine kavuştuğu bir dönemde yazılmış olması, bir sahabe olan Selmân b. Fârisî’nin oluşumunu işlemesi açısından önemlidir. Ayrıca onun, İslam tarihinin ilk dönemiyle ilgili okuyucuya bilgiler sunması da kayda değerdir. Dolayısıyla bu eser, bir bildungsroman örneği olmakla beraber tarihî ve sosyal bir hüviyete de sahiptir.

Eser, Selmân b. Fârisî’nin inançları üzerinden kendini gerçekleştirme uğruna çıktığı yolculuğu anlatır. Fars diyarında başlayan Anadolu, Irak, Suriye ve en sonunda Medine'de biten oluşum mücadelesi dikkat çeker. Fârisî’nin yaşadığı bütün sevinç ve kederin sonunda onun kendini gerçekleştirmesi vardır. Roman başkahramanı Selmân'ın bu eşsiz oluşumunu tahkiye ettiği için Arap edebiyatında bir bildungsroman örneği olarak yer almaktadır.

\section{Kaynakça}

'Abdullah, Muhammed 'Abdulhalîm (ts.), el-Bâhis 'ani'l-hakîka, Dâru'l-kitâbi'lMısrî, Kâhire.

'Âşûr, Radvâ (2009) el-Hedâsetu'l-mumkine, eş-Şidyâk ve's-sâk alâ's-sâk errivâyetu'l-ulâ fí'l-edebi'l- 'Arabî'l-hadîs, Dâru'ş-şurûk.

Asutay, Hikmet (2012) "Oluşum Romanı Geleneği ile Günümüzdeki İzleri Üzerine”, ZfWT Vol. 4, No. 2, ss. 27-35.

Aytekin, Arif (2017), “Delâilü’n-nübüvve' ye Konu Teşkil Eden İki Sahâbî: Selmân-1 Farisî ve Abdullah b. Selâm)" Düzce Üniversitesi Illahiyat Fakültesi Dergisi, 1/1, ss. 27-40.

Al-Mutairi, Reham Fahad (2016), "Reconciling Two Opposing Cultures: The Bamboo Stalk and the Arabic Bildungsroman", Arab World English Journal (AWEJ), 7/2, ss. 358-367.

Turkish Academic Research Review - Türk Akademik Araştırmalar Dergisi 
Badawi, M.M. (1992) Modern Arabic Literature, Cambridge University Press.

Bayram, Yavuz (2007) "Bildungsroman Örneği Olarak Hüsn-ü Aşk”, İlmî Araştırmalar, Sayı: 23, ss. 7-28.

Er, Rahmi (2015), Modern Misır Romanı, 1914-1944, Hece Yayınları, Ankara.

Golban, Petru (2017). "Bildungsromanın Tarihsel Gelişimine Bir Bakış: Antik Dönemden Romantik Döneme Bildungsroman Alt Türünün Ortaya Çıkışı” Humanitas 5/10. ss.111- 141.

el-Hâdîb, Muhammed Kâmil (1976), el-Muğâmeretu'l-mu'akkıda, Menûşrât vizâreti's-sekâfe ve'l-irşâdi'l-kavmî.

Kutluer, İlhan-Katipoğlu, Hasan (1997), "Hay b. Yakzân” TDV İslâm Ansiklopedisi, (DIA), c. 16, İstanbul, ss. 551-554.

el-Ka‘ûd, Hilmî Muhammed (1976), el-ğurûbu'l-mustehîl: sîretu kâtib Muhammed 'Abdulhalim 'Abdullah, el-meclisu'l-e'lâ liri'aeti'l-funûn ve'l-adâb ve'l'ulûmi'l-ictimâ'îyye, yy.

Nâcî, ‘Abdû'r- Ruûf Abdu'd-dâyîm (2009), Rural and Provincial Locale in Some of the Novels Tho-mas Hardy (1840-1928) and Mohammed Abdel-Halim Abdallah (1913-1970), (Yayınlanmamış Yüksek Lisans Tezi), ‘Aın Shams University, Women's College for Arts, Science and Educa-tion English Department, Kahire.

Nedal, Al-Mousa (2006), "The changing image of the heroine in the Arabic female Bildungsroman”, Middle Eastern Literatures, 9:3, ss.257-270.

Nevfel, Yusûf Hasan (1981), Muhammed 'Abdulhalîm 'Abdullah hayâtuhû ve edebuhû, Kulliyetu'l-âdâb.

Özalp, N. Ahmed (2014), Hay Bin Yakzan, Yapı Kredi yayınları, İstanbul.

Özdemir, Ayşe Nur (2018), “Tersine Bir Bildungsroman: Tante Rosa”, Trakya Üniversitesi Sosyal Bilimler Dergisi, 20/ 2, ss. 497-507.

Parla, Jale-Akarl1, Engin (1978). "Roman ve Toplum Sorunları”. Boğaziçi Üniversitesi Dergisi, Sayı: 6, ss. 239-245.

Tanrıtanır, Bülent Cercis ve Eleman, Akın (2007) "Bildungsroman Olarak F. S. Fitzgerald'in This Side Of Paradise Adlı Romanı" Atatürk Üniversitesi Sosyal Bilimler Enstitüsü Dergisi, 9/1, ss. 65-79.

Ürün, Ahmet Kâzım (2018) Modern Arap Edebiyatı, Çizgi Kitabevi, Konya. 